\title{
Influence of the addition of "synthetic termite saliva" in the compressive strength and water absorption of compacted soil-cement
}

\author{
Influência da adição de "baba de cupim sintética" na \\ resistência à compressão e absorção de água de solo- \\ cimento compactado
}

\begin{abstract}
Obede Borges Faria
Rosane Aparecida Gomes Battistelle

Célia Neves

\section{Abstract}

$\mathbf{T}$

he aim of this paper is to determine the effect of adding $0.1 \mathrm{wt} \%$ of "synthetic termite saliva" on a fine and clayey sand latosol $(76.5 \%$ sand) from the region of Bauru, SP (Brazil), stabilized with $1 \%$ to $3 \%$ of cement. Compacted cylindrical specimens (with standard Proctor energy) were tested to determine their compressive strength and water absorption. The results indicate that the use of the chemical stabilizer increased by at least $35 \%$ the compressive strength and reduced by up to $13 \%$ the water absorption of the samples. This work contributes to efforts aimed at reducing the consumption of cement through the production of stabilized compressed earth blocks and bricks (CEB) and rammed earth.

Obede Borges Faria Universidade Estadual Paulista Júlio de Mesquita Filho Bauru - SP - Brasil

Rosane Aparercida Gomes Battistelle Universidade Estadual Paulista Júlio de Mesquita Filho Bauru - SP - Brasil

Célia Neves Rede Ibero-americana PROTERRA; Rede TerraBrasil Seattle - WA - USA

Recebido em 02/08/14 Aceito em 13/02/16

Keywords: Earthen architecture and construction. Compacted soil-cement. Synthetic termite saliva. Compressive strength. Water absorption.

\section{Resumo}

Este trabalho apresenta um estudo realizado para avaliar o efeito da adição de $0,1 \%$ em massa de "baba de cupim sintética" em um latossolo arenoargiloso fino (76,5\% de areia), proveniente da região de Bauru, SP, Brasil, estabilizado com $1 \%$ a $3 \%$ de cimento. Foram ensaiados corpos de prova cilíndricos (compactados com energia Proctor normal) para determinar sua resistência à compressão e sua absorção de água. Os resultados indicam que o uso do aditivo produziu aumento de pelo menos $35 \%$ na resistência à compressão e reduziu em até $13 \%$ a absorção de água das amostras. $O$ trabalho contribui com os esforços de redução do consumo de cimento na construção civil, através da produção de blocos (e tijolos) de terra comprimida (BTC) estabilizada e taipa.

Palavras-chaves: Arquitetura e construção com terra. Solo-cimento compactado. Baba de cupim sintética. Resistência à compressão. Absorção de água.
\end{abstract} v. 16, n. 3, p. 127-136, jul./set. 2016. 


\section{Introduction}

All building materials cause environmental impacts, since they use natural resources as raw materials. However, some materials cause greater impacts, consuming larger amounts of energy and generating more wastes. Although earth is one of the oldest building materials, it is one of the least impacting and fortunately it is still used quite intensively, contrary to many misconceptions. It remains, therefore, to find ways to upgrade longstanding earth construction techniques by including new technologies and modern products that can enhance their quality and durability, while simultaneously contributing to the quest for sustainable development.

In this context, a synthetic product was launched on the Brazilian market in the 1970s, which causes low environmental impacts and whose properties supposedly give to the soil a cohesive strength very similar to that obtained by termites in the construction of their nests, according to Milogo, Hajjaji and Morel (2011). Due to this property, the product became known popularly as "synthetic termite saliva". As with all novelties, the product was soon attributed wonderful or even almost miraculous properties, which were not based on solid scientific evidence, which is why there are no references in the international literature on the use of this chemical stabilizer in compacted or compressed soil-cement.

Silva (2007) studied the performance of nine types of chemical stabilizers for soils (including cement, lime and "synthetic termite saliva"), however, from the standpoint of soil mechanics and not applying the soil as a construction material. This author used a silty-sandy soil and $2 \%$ lime as reagent for the "synthetic termite saliva". Thus, their results can not be compared with those obtained in the present study.

Corrêa et al. (2015) studied the use of the same chemical stabilizer - activated with aluminum sulfate, $\mathrm{Al}_{2}\left(\mathrm{SO}_{4}\right)$ - in adobes and found very positive results. However, adobe and the material studied in the present work (compacted soilcement) are very different, as well as the soils used in both papers. These authors also cite only two references on chemical stabilization of soils.

Several researchers in Mexico have studied the use of a natural product (not industrialized) physically resembling "synthetic termite saliva" obtained from the sap of nopal cactus, the popular name of several plants of the genus Opuntia pilifera of the family Cactaceae, which are endemic in the Americas, with high occurrence and a variety of uses in Mexico. Some have evaluated only the sealing properties of this product for the restoration of old buildings (DANEELS; GUERRERO BOCA; ROUX GUTIÉRREZ, 2009) and in new constructions (MÚJICA; LÓPEZ, 2009). The influence of this material and of mucilage from Aloe barbadensis on the physical and mechanical properties of compressed earth blocks (hereinafter referred to as CEB), produced with the addition of these products in mixing water, was studied by Aranda Jiménez (2010).

In addition to the fact that soil is an extremely variable raw material due to its granulometric, mineralogical and chemical composition, there is no single methodology to determine the characteristics of materials produced with soil, so each author adopts his own methodology, adapted from the few existing technical standards for these materials. Hence, it is very difficult to make consistent and pertinent comparisons of the results obtained by different researchers.

Concern about the lack of scientific research on "synthetic termite saliva" in compressed or compacted soil-cement prompted the presentation of a proposal to the Ibero-American PROTERRA network (www.redproterra.org), according to Neves and Faria (2008), to identify people and/or institutions willing to engage in scientific studies on the subject. However, besides the authors of this paper, so far only one other research group has focused on this theme (MILANI et al., 2010).

The main Brazilian manufacturer of machines to produce soil-cement blocks and bricks recommends two proportions (mixes), in volume (SAHARA, 2010):

(a) 1:7 to 1:10 (one volume of cement for 7 to 10 volumes of loose soil) - for non-mortared brick walls; and

(b) 1:15 (one volume of cement to 15 of loose soil) - for mortared walls.

These mixes correspond to approximately $17 \%$ and $8 \%$, respectively, in mass, i.e., mass percentage of cement to that of dry soil. In both cases, compaction moisture of $5 \%$ and soil with sand content varying from $50 \%$ to $70 \%$ are recommended (SAHARA, 2010). Other authors suggest a volume mix of $1: 10$ to $1: 20$ (INSTITUTO..., 2010). However, this is not based on any scientific reference.

On the other hand, the two Brazilian manufacturers of "synthetic termite saliva" recommend the use of this chemical stabilizer together with a reactive agent, which may be cement in a very low proportion, $1 \%$ to $3 \%$ of cement in relation to dry 
soil weight (DYNASOLO, 2014; ECOLOPAVI..., 2010). Lime and aluminum sulfate can also be used as reagents for the chemical stabilizer (DYNASOLO, 2014).

Thus, the main objective of this paper is to present the results of tests to assess the influence of one of the two brands of "synthetic termite saliva" produced in Brazil, on the water absorption and compressive strength of soil-cement produced with a dark red - yellow latosol, texturally classified as fine and clayey sand soil, from the region of Bauru, in the state of São Paulo, Brazil.

\section{Materials and experimental procedures}

The soil used here came from the municipality of Bauru, SP, and is predominantly sandy, according to Faria (2002), Faria et al. (2008, 2010), Faria, Garcia and Falavigna (2007), Faria, Stanzione and Miller (2009) and Agnelli (1997). Soil samples were prepared according to the procedures recommended by the Brazilian NBR 6457 standard (ABNT, 1986). The test to determine the particle size distribution curve was performed according to the NBR 7181 standard (ABNT, 1984b), while the liquid limit (LL) was determined according to the NBR 6459 standard (ABNT, 1984a). Because this soil is extremely sandy (77\% sand), its plastic limit (PL) could not be determined and therefore its plasticity index (PI) could not be calculated. The tests to determine the compaction curve and the apparent density of the loose dry soil are described below.

"Synthetic termite saliva", is a chemical stabilizer based on vegetable oils and resins, which is designed to stabilize soils used in road paving and other similar situations, like parking, sports court and industrial courtyards. This product is highly concentrated and totally water-soluble, non-toxic, non-corrosive and non-flammable. It is green and has a density of $1,040 \mathrm{~g} / \mathrm{cm}^{3}$ (at $25^{\circ} \mathrm{C}$ ) and minimum $\mathrm{pH}$ of 10.5 (1\% solution) (DYNASOLO, 2014).

A high early strength Portland cement (CP V-ARI) was used as a reagent for the chemical stabilizer. Considering that the main objective was to evaluate the effects of the chemical stabilizer, it was decided to use cement only as a reactant, in amounts varying from $1 \%$ to $3 \%$, and to use the highest concentration of the "synthetic termite saliva" recommended by the manufacturer (DYNASOLO, 2014), i.e., 1:1000 (1 kg of chemical stabilizer for each $1,000 \mathrm{~kg}$ of dry soil). Thus, it sought to highlight the effect of the chemical stabilizer on the soil.

\section{Determination of the unit weight of the loose soil}

The soil-cement dosages recommended by machine manufacturers for CEB refer to the volume ratio of soil to cement (SAHARA, 2010). However, in the laboratory, it is advisable to work with the weight ratio in order to ensure stricter control of the quantities of components used. Therefore, it was necessary to determine the apparent density or unit mass of damp loose soil $\left(\rho_{\text {ssu }}\right)$, in order to convert the volume ratios to weight ratios, or vice versa. Since there are no technical standards to determine this parameter in soil, it was adopted the methodology proposed by Faria (2002) and previously evaluated by Faria, Garcia and Falavigna (2007), Faria, Stanzione and Miller (2009) and Faria et al. (2010), which consists of an adaptation of the NM 45 standard (ABNT, 2006).

Because variations in moisture content can cause swelling of loose soil, especially sandy soils such as the one used in this work, it is also necessary to know the hygroscopic or natural moisture, $\left(\mathrm{W}_{\mathbf{h}}\right)$, of loose soil, which is determined by standard procedures in soil mechanics laboratories.

\section{Soil compaction test}

The soil compaction test enables one to define the compaction curve and determine the optimum moisture content for compaction $\left(\mathrm{W}_{\text {opt }}\right)$ at the maximum dry density of compacted soil $\left(\rho_{\mathbf{d}, \max }\right)$. These parameters are very important in the production of soil-cement with maximum strength and durability, because the more compacted the soil the lower its porosity. This test was performed according to the NBR 7182 standard (ABNT, 1988), with standard Proctor energy - hammer weight of $(2,500 \pm 10) \mathrm{g}$, drop distance of $(305 \pm$ 2) $\mathrm{mm}$, three layers with 26 blows per layer, in a mould of diameter $100 \mathrm{~mm}$ and height of 127.3 $\mathrm{mm}$.

\section{Soil-cement tests}

\section{Soil-cement compaction test}

As the tests were conducted with soil mixed with cement, there was the possibility that the optimum moisture content for compaction of the mixture would differ from that found only for soil. It was therefore decided to perform a new compaction test of a mixture containing $9 \%$ of cement, which is the average of the amounts recommended by manufacturers of machinery for soil-cement bricks and blocks, to evaluate the influence of cement on the optimum compaction moisture. This test was 
performed according to the NBR 12023 standard (ABNT, 2012a), with standard Proctor energy.

\section{Molding and curing of test specimens}

Specimens with a diameter of $100 \mathrm{~mm}$ and height of $127.3 \mathrm{~mm}$ (like those used in the compaction test, with the same standard Proctor energy), were molded and subjected to moist curing, as specified by the NBR 12024 standard (ABNT, 2012b) A total of six specimens of each of the following series were molded and cured:

(a) $1 \%, 2 \%$ and $3 \%$ of cement, without chemical stabilizer; and

(b) $1 \%, 2 \%$ and $3 \%$ of cement, with chemical stabilizer.

Three specimens of each series were tested to determine their compressive strength and 3 were tested to determine their water absorption. This number of specimens subjected to each test is recommended by the corresponding standards.

In order to reach the optimum compaction moisture, the hygroscopic moisture of the soil was first determined and the amount of water to be added was calculated, always considering the total mass of the dry solid material (soil + cement) for each mixture. All the materials were measured in terms of mass, including the water, to ensure the strictest possible control of the quantities and proportions of materials in the mixtures.

Following the recommendation of the "synthetic termite saliva" manufacturer (DYNASOLO, 2014), the chemical stabilizer was mixed with the soil before adding the cement. To this end, it was diluted in half the required amount of water, and distributed uniformly in the soil. The cement was then added, and lastly the remaining water, and the mixture was thoroughly homogenized, observing a certain difficulty of water incorporating to the mixture (Figure 1).

\section{Water absorption test}

After curing the specimens in a moist chamber for seven days, as specified by the NBR 12024 standard (ABNT, 2012b), the water absorption (WA) test was performed according to the NBR 13555 standard (ABNT, 2012e), which involves leaving the specimens in an oven at $105^{\circ} \mathrm{C}$ ) for 24 hours, followed by the determination of its dry mass, cooling, immersion in water for $24 \mathrm{~h}$, and determination of its saturated mass.

\section{Compressive strength test}

The tests to determine compressive strength $\left(f_{c}\right)$ were performed as specified by the NBR 12025 standard (ABNT, 2012c). This test involves the following steps: submerge the specimens (cured and at 7 days of age) in water for $4 \mathrm{~h}$; remove them from the water and dry their surfaces with a damp cloth; measure their diameters and height $(0.1 \mathrm{~mm}$ precision); place them correctly in the testing machine; apply the load by moving the loading head at a rate of $1 \mathrm{~mm} / \mathrm{min}$, until rupture of the specimen occurs; and., record the specimen's rupture load.

The standard establishes that flat and horizontal load application surfaces do not have to be regularized. These tests were performed on an EMIC DL300 universal testing machine with a loading capacity of up to $30,000 \mathrm{kgf}$, as well as the rupture pattern of the cylindrical specimens (Figure 2).

Figure 1 - Preparation of soil-cement with chemical stabilizer, noting the "impermeability" of the mixture (soil, cement and chemical stabilizer)

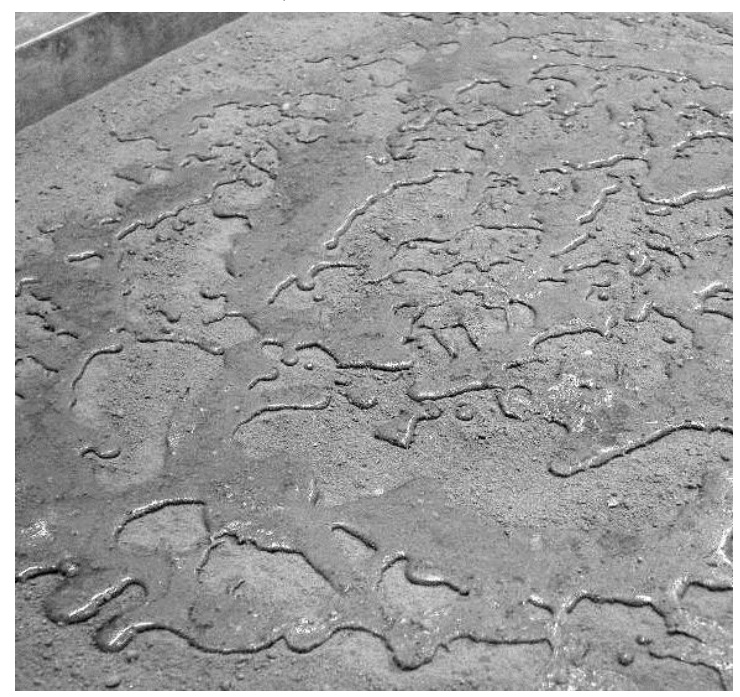

130 Faria, O. B.; Battistelle, R. A. G.; Neves, C. 
Figure 2 - Compressive strength testing: rupture pattern of the saturated specimen, showing the stress cone, with lateral and peripheral detachment of the material in layers



\section{Results and discussion}

\section{Characteristics of the soil}

The grain size distribution curve of the soil indicated a soil consisting of $18.2 \%$ clay, $5.3 \%$ silt and $76.5 \%$ sand $(44.5 \%$ fine, $31.9 \%$ intermediate, $0.1 \%$ coarse), which can be classified as "sandy soil" (NEVES et al., 2011), very similar to a "clayey-sandy soil." This soil was thoroughly studied and classified by Agnelli (1997), which showed the following results: regarding the genesis, residual soil of sandstone; according to pedology, dark red - yellow latosol; texturally classified as fine and clayey sand and, according to Highway Research Board (HBR), a sandy soil of the A-2-4 group. Mineralogical analysis conducted by this author, by $\mathrm{X}$-ray diffraction (XRD), pointed out that the predominant clay-mineral is the kaolinite $\left[\mathrm{Al}_{2} \mathrm{Si}_{2} \mathrm{O}_{5}(\mathrm{OH})_{4}\right]$. This soil is suitable for the production of $\mathrm{CEB}$ and rammed earth, even without stabilization (JIMENEZ DELGADO; GUERRERO, 2006, 2007; NEVES; MILANI, 2011).

The liquid limit (LL) obtained was $26.5 \%$, which is typical of sandy soil. However, due to the high sand content, the plastic limit (PL) could not be determined, and therefore the plasticity index (PI) was not calculated. The PI is one of the most suitable indicators of the technique for use with soil used as a construction material, but it is not always possible to determine this index (VENKATARAMA REDDY; PRASANNA KUMAR, 2011).

The apparent density of the damp soil, or unit mass of moist loose soil $\left(\rho_{\mathrm{ssU}}\right)$, was $1.25 \mathrm{~g} / \mathrm{cm}^{3}$ for a hygroscopic moisture or natural moisture content $\left(\mathrm{W}_{\mathbf{h}}\right)$ of $0.88 \%$. It should be noted that these two parameters should always be determined because

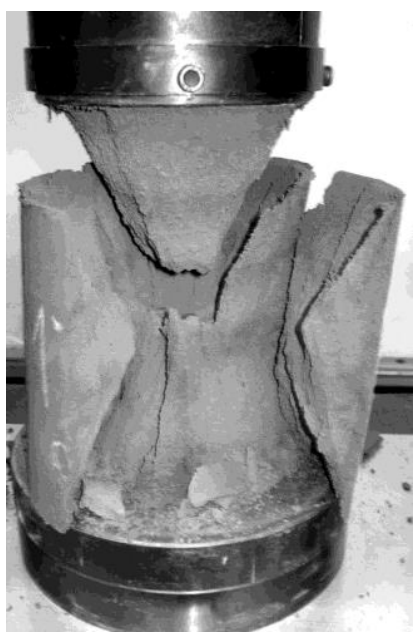

they vary according to local climate conditions (especially relative air humidity and temperature) and directly affect other parameters.

The soil's compaction curve (Figure 3 ) was used to determine the optimum moisture content for compaction $\left(\mathrm{W}_{\text {opt }}\right)$ of $12.0 \%$, with a maximum dry density of the compacted soil $\left(\rho_{\mathbf{d}, \max }\right)$ of $1.92 \mathrm{~g} / \mathrm{cm}^{3}$, which is also characteristic of sandy soils.

\section{Compaction of the soil-cement}

The optimum compaction moisture for the mixture of soil and $9 \%$ of cement was $\mathrm{W}_{\text {opt }}=12.1 \%$, with a maximum dry density $\left(\rho_{\mathbf{d}, \max }\right)$ of $1.90 \mathrm{~g} / \mathrm{cm}^{3}$, which are values very similar to those of pure soil (Figure 3). These results confirm that the addition of cement did not affect these parameters; hence, a single optimum moisture content for compaction was adopted for the three cement contents tested in this work $(1 \%, 2 \%$ and $3 \%)$.

These results are very close to those reported by Venkatarama Reddy and Prasanna Kumar (2011) $\left(\mathrm{W}_{\text {opt }}=12.1 \%\right.$ and $\left.\rho_{\mathrm{d}, \max }=1.90 \mathrm{~g} / \mathrm{cm}^{3}\right)$, who worked with a soil containing $72.6 \%$ sand, $11.6 \%$ silt and $15.8 \%$ clay, which is similar to the soil stabilized with $5 \%$ cement used in the present work, used in specimens of cement stabilized rammed earth (CSRE).

In this step, when the second half of the water was added to the soil-chemical stabilizer-cement mixture, there was already visible evidence of the influence of the chemical stabilizer on the behavior of the soil-cement, i.e., the added water did not infiltrate as easily as when it was added to the soil without chemical stabilizer (Figure 1), giving the impression that the mixture was impermeable. 
Figure 3 - Compaction curves of soil and soil-cement



\section{Water absorption of the soil-cement}

Average results of the water absorption (WA) tests with three specimens of each series are shown in Table 1. The specimens of the series without chemical stabilizer and with $1 \%$ of cement disintegrated during immersion in water, so their water absorption rate could not be calculated. The specimens with chemical stabilizer and $1 \%$ of cement showed fairly high detachment of the material during immersion. With $2 \%$ and $3 \%$ of cement, such detachment was imperceptible, suggesting the aggregative property of the chemical stabilizer.

At the higher cement contents (2\% and $3 \%)$ there was a significant decrease of more than $12 \%$ in water absorption with the use of the chemical stabilizer. However, it cannot be stated that this advantage would remain constant at this level with cement contents of more than $3 \%$.

WA with $3 \%$ of cement and the chemical stabilizer was $11.8 \%$, which is very close to the value $11.5 \%$ reported by Venkatarama Reddy and Prasanna Kumar (2011) and much lower than the $18.1 \%$ found by Morel, Pkla and Walker (2007). They worked with a soil containing $18 \%$ clay (very similar to that used in the present work), stabilized with $5 \%$ cement.

The CEB studied by Aranda Jiménez (2010), with the addition of sap of nopal cactus and Aloe barbadensis mucilage, stabilized with $6 \%$ cement, showed water absorption of close to $8 \%$.

\section{Compressive strength of the soil- cement}

Average results of the compressive strength tests, at seven days age of the specimens for each addition rate of cement, as well as strength gain by adding the chemical stabilizer are shown in Table 2.

An analysis of the results presented here allows one to infer that the compressive strength $\left(f_{c}\right)$ increased considerably with the use of the chemical stabilizer. This increase was close to $125 \%$ with $1 \%$ of cement content, and of $35 \%$ with $3 \%$ cement.

These results contradict those reported by Milani et al. (2010), who concluded that the use of the chemical stabilizer did not lead to a significant improvement. Because these authors were the first to start the research, they made a minor error in their interpretation of the dosage recommended by the manufacturer of the chemical stabilizer. The recommended proportion is $1: 1000$, i.e., $1 \mathrm{~kg}$ of chemical stabilizer for every $1000 \mathrm{~kg}$ of dry soil. The aforementioned authors diluted $50 \mathrm{ml}$ of chemical stabilizer in $1000 \mathrm{ml}$ water to obtain a $5 \%$ solution. Then they used $1 \mathrm{~kg}$ of this solution for $1000 \mathrm{~kg}$ of dry soil and hence, the real proportion in mass was approximately 1:20,000, which is extremely low and which resulted in making it impossible to perceive the action of the chemical stabilizer.

The results of $f_{c}$ found in the present work (3.18 MPa, with chemical stabilizer and $3 \%$ cement) are slightly lower than those reported by Aranda Jiménez (2010), which varied from 3 to $5 \mathrm{MPa}$. However, this author tested dry specimens 
but not saturated ones, and also did not explain the test methodology employed.

On the other hand, Venkatarama Reddy and Prasanna Kumar (2011) obtained $\mathrm{f}_{\mathrm{c}}=1.9 \mathrm{MPa}$ using $5 \%$ of cement, while Walker and Stace (1997) obtained $2.4 \mathrm{MPa}$ using $5 \%$ cement, and Morel, Pkla and Walker (2007) reported $2.2 \mathrm{MPa}$ using $3 \%$ cement. All these results were lower than those of the present work, which may also indicate the advantage of using "synthetic termite saliva".

The use of the chemical stabilizer also offers an advantage from the standpoint of environmental sustainability. Aiming for a given compressive strength for compressed earth blocks or bricks (CEB), it was found that the addition of the chemical stabilizer enabled a reduction in the consumption of cement (Figure 4). For example, to obtain a compressive strength of $2.0 \mathrm{MPa}$ without using chemical stabilizer would require a cement content of $2.65 \%$. With the use of the chemical stabilizer, this content would drop to $1.98 \%$, thus translating into a $25.28 \%$ reduction in the consumption of cement. The fact that cement is a material that causes much greater environmental impact than the chemical stabilizer confirms the advantage of using the latter.

Table 1 - Water absorption values (WA), standard deviation (sd) and variation coefficient (CV)

\begin{tabular}{|c|c|c|c|c|c|c|c|}
\hline \multirow{2}{*}{$\begin{array}{l}\text { Cement } \\
(\% \text { in } \\
\text { mass })\end{array}$} & \multicolumn{3}{|c|}{ Without chemical stabilizer } & \multicolumn{3}{|c|}{ With chemical stabilizer } & \multirow[b]{2}{*}{$\begin{array}{c}\text { Water absorption } \\
\text { decrease (\%) }\end{array}$} \\
\hline & $\begin{array}{l}\text { WA } \\
(\%)\end{array}$ & $\begin{array}{l}\text { sd } \\
(\%)\end{array}$ & $\begin{array}{l}\text { CV } \\
(\%) \\
\end{array}$ & $\begin{array}{l}\text { WA } \\
(\%) \\
\end{array}$ & $\begin{array}{l}\text { sd } \\
(\%)\end{array}$ & $\begin{array}{l}\text { CV } \\
(\%)\end{array}$ & \\
\hline $\mathbf{1}$ & $\overline{--}$ & -- & -- & 10.34 & 0.17 & 1.64 & - \\
\hline 2 & 12.53 & 0.22 & 1.76 & 10.88 & 0.03 & 0.28 & 13.11 \\
\hline 3 & 12.60 & 0.45 & 3.57 & 11.08 & 0.32 & 2.89 & 12.03 \\
\hline
\end{tabular}

Table 2 - Average compressive strength values $\left(f_{c}\right)$, standard deviation $(\mathbf{s d})$, variation coefficient (CV) and compressive strength variation

\begin{tabular}{c|c|c|c|c|c|c|c}
\hline $\begin{array}{c}\text { Cement } \\
(\boldsymbol{\%} \text { in } \\
\text { mass) }\end{array}$ & \multicolumn{2}{|c|}{ Without chemical stabilizer } & \multicolumn{2}{|c|}{ With chemical stabilizer } & Compressive \\
\cline { 2 - 7 } & $\begin{array}{c}\mathbf{f}_{\mathbf{c}} \\
(\mathbf{M P a})\end{array}$ & $\begin{array}{c}\text { sd } \\
(\mathbf{M P a})\end{array}$ & $\begin{array}{c}\mathbf{C V} \\
\mathbf{( \% )}\end{array}$ & $\begin{array}{c}\mathbf{f}_{\mathbf{c}} \\
(\mathbf{M P a})\end{array}$ & $\begin{array}{c}\text { sd } \\
(\mathbf{M P a})\end{array}$ & $\begin{array}{c}\mathbf{C V} \\
(\boldsymbol{\%})\end{array}$ & $\begin{array}{c}\text { strength } \\
\text { increase }(\boldsymbol{\%})\end{array}$ \\
\hline $\mathbf{1}$ & 0.28 & 0.04 & 14.29 & 0.63 & 0.08 & 12.70 & 125 \\
$\mathbf{2}$ & 1.33 & 0.12 & 9.02 & 2.03 & 0.26 & 12.81 & 53 \\
$\mathbf{3}$ & 2.36 & 0.27 & 11.44 & 3.18 & 0.11 & 3.46 & 35 \\
\hline
\end{tabular}

Figure 4 - Reduced cement consumption when using "synthetic termite saliva" (STS), with no change in compressive strength

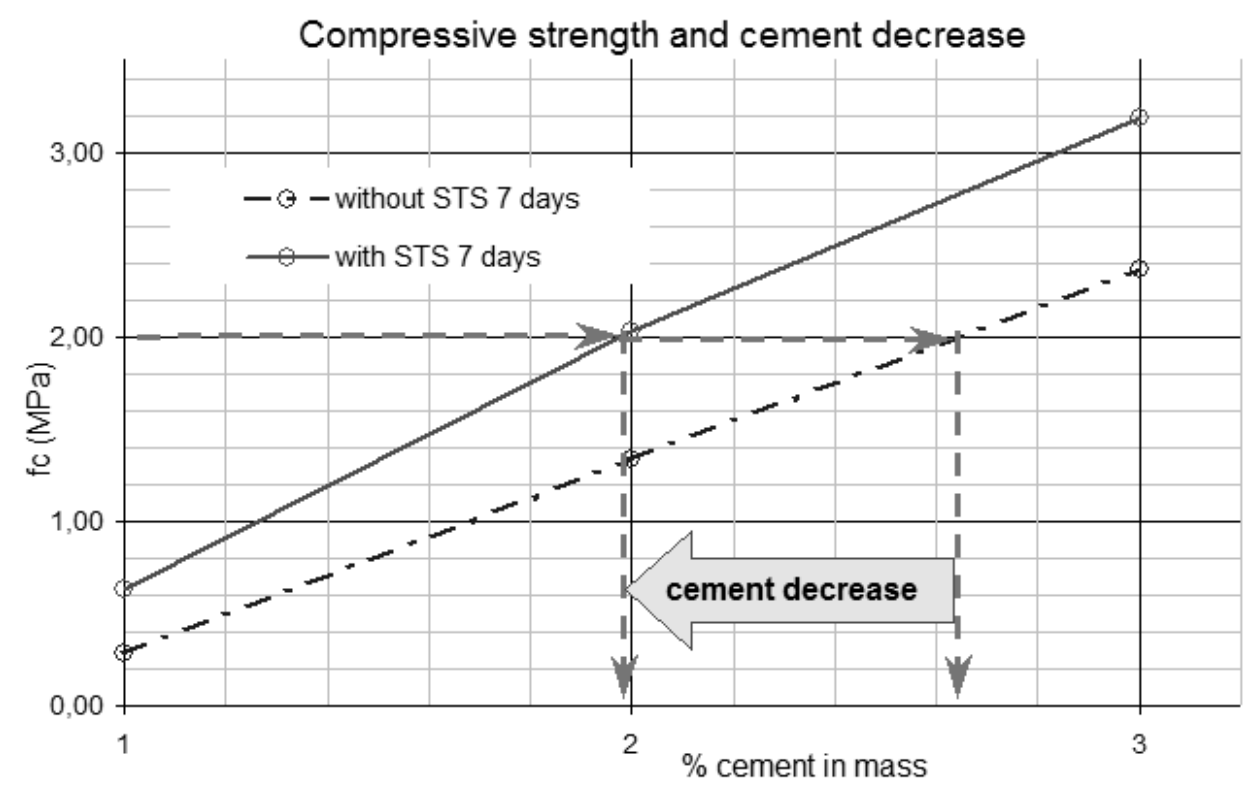




\section{Conclusions}

The study of compacted soil-cement specimens allows for a more direct application of the results in the production of rammed earth, because this is a technique which also involves compacting soil (application of dynamic loads) which can also be stabilized with cement or other chemical stabilizers. However, these results can also be applied in the production of CEB, which involves compressing the soil (application of static loads).

The results of this study indicate several advantages obtained with the use of chemical stabilizer. However, it is more prudent to consider this work as a pioneer study for the definition of a methodological strategy that serves as the basis for future, more complete investigations of a broader scope.

For instance, it would be desirable to study the durability of the material, according to the proposal of the Brazilian NBR 13554 standard (ABNT, 2012d). It would also be necessary to carry out tests with cement contents of more than $3 \%$ to determine whether the advantages of using chemical stabilizer continue to increase at the same level as that found in the present study.

Another important aspect observed in this work has to do with sampling. The Brazilian NBR 12025 standard (ABNT, 2012c) recommends the use of 3 specimens for compressive strength testing, but it is believed that an increase to at least 5 specimens could be proposed, and that 10 is the ideal number for a better statistical evaluation of the results.

Moreover, considering the fact that lime is more environmentally friendly than cement, and that it can also be used as a reagent for the chemical stabilizer (ECOLOPAVI..., 2010; DYNASOLO, 2014), it is suggested that further research should focus on evaluating the influence of the chemical stabilizer on soil-lime bricks.

This paper presents an extensive list of Brazilian standards for soil-cement, but all of them focus on CEB. This fact indicates that there is a large gap in standards for rammed earth and monolithic soilcement panels, and points to the need for the development of research into this particular theme.

\section{References}

AGNELLI, N. Comportamento de Um Solo Colapsível Inundado Com Líquidos de Diferentes Composições Químicas. São Carlos, 1997. 205 f. Tese (Doutorado em Geotecnia) Escola de Engenharia de São Carlos, Universidade de São Paulo, São Carlos, 1997.
ARANDA JIMÉNEZ, Y. G. BTC Adicionado con Diferentes Concentraciones de Mucílago de Nopal y Aloe en el Agua de Mezcla. In: SEMINÁRIO IBEROAMERICANO DE CONSTRUCCIÓN CON TIERRA, 10., Salto, 2010. Proceedings.... Salto: PROTERRA/UdeLaR, 2010.

ASSOCIAÇÃO BRASILEIRA DE NORMAS TÉCNICAS. NBR 12023: solo-cimento: ensaio de compactação. Rio de Janeiro, 2012a.

\section{ASSOCIAÇÃO BRASILEIRA DE NORMAS} TÉCNICAS. NBR 12024: solo-cimento: moldagem e cura de corpos de prova cilíndricos: procedimento. Rio de Janeiro, 2012b.

ASSOCIAÇÃO BRASILEIRA DE NORMAS TÉCNICAS. NBR 12025: solo-cimento: ensaio de compressão simples de corpos de prova cilíndricos: método de ensaio. Rio de Janeiro, 2012c.

\section{ASSOCIAÇÃO BRASILEIRA DE NORMAS}

TÉCNICAS. NBR 13554: solo-cimento: ensaio de durabilidade por molhagem e secagem: método de ensaio. Rio de Janeiro, 2012d.

\section{ASSOCIAÇÃO BRASILEIRA DE NORMAS}

TÉCNICAS. NBR 13555: solo-cimento: determinação da absorção de água: método de ensaio. Rio de Janeiro, 2012e.

\section{ASSOCIAÇÃO BRASILEIRA DE NORMAS} TÉCNICAS. NBR 6457: amostras de solo: preparação para ensaios de compactação e ensaios de caracterização. Rio de Janeiro, 1986.

\section{ASSOCIAÇÃO BRASILEIRA DE NORMAS} TÉCNICAS. NBR 6459: solo: determinação do limite de liquidez. Rio de Janeiro, 1984a.

\section{ASSOCIAÇÃO BRASILEIRA DE NORMAS \\ TÉCNICAS. NBR 7181: solo: análise granulométrica. Rio de Janeiro, 1984b.}

\section{ASSOCIAÇÃO BRASILEIRA DE NORMAS}

TÉCNICAS. NBR 7182: solo: ensaio de compactação. Rio de Janeiro, 1988.

\section{ASSOCIAÇÃO BRASILEIRA DE NORMAS TÉCNICAS. NBR NM 45: agregados: determinação da massa unitária e do volume de vazios. Rio de Janeiro, 2006.}

CORRÊA, A. A. R. et al. Incorporation of Bamboo Particles and "Synthetic Termite Saliva" in Adobes. Construction and Building Materials, v. 98, p. 250-256, 2015. 
DANEELS, A. J. E.; GUERRERO BACA, L. F.; ROUX GUTIÉRREZ, R. S. Labores Preliminares de Conservación de la Pirámide de la Joya, Veracruz, Mexico. In: SEMINÁRIO IBEROAMERICANO DE CONSTRUCCIÓN CON TIERRA, 7.; SEMINÁRIO ARGENTINO DE ARQUITECTURA Y CONSTRUCCIÓN CON TIERRA, 2., San Miguel de Tucumán, 2009. Anais... San Miguel de Tucumán: PROTERRA/UNT, 2009.

DYNASOLO. A Tecnologia da Baba de Cupim na Construção Civil. São Paulo: Dynasolo, 2014.

ECOLOPAVI ESTABILIZANTE QUÍMICO. O Que é Ecolopavi: estabilizante químico de solos para pavimentação. Manaus: Ecolopavi, 2010.

FARIA, O. B. Utilização de Macrófitas Aquáticas na Produção de Adobes: um estudo de caso na Represa de Salto Grande (Americana SP). São Carlos, 2002. 200 f. Tese (Doutorado em Ciências da Engenharia Ambiental) - Escola de Engenharia de São Carlos, Universidade de São Paulo, São Carlos, 2002.

FARIA, O. B. et al. Avaliação de Proposta Metodológica Para Caracterização Física e Mecânica de Adobes. In: FERNANDES, M.; CORREIA, M.; JORGE, F. (Orgs.). Terra em Seminário. Lisboa: Argumentum; 2010.

FARIA, O. B.; GARCIA, A. R.; FALAVIGNA, J. P. T. Otimização do Uso de Biomassa de Eichhornia crassipes e Sedimento do Reservatório de Salto Grande (Americana-SP, Brasil) na Produção de Adobe. In: NEVES, C. M. M. et al. (Orgs.). Terra em Seminário 2007. Lisboa: Argumentum, 2007.

FARIA, O. B. et al. Realização dos Ensaios InterLaboratoriais PROTERRA em Bauru-SP, Brasil. In: SEMINÁRIO IBERO-AMERICANO DE CONSTRUÇÃO COM TERRA, 7.; CONGRESSO DE ARQUITETURA E CONSTRUÇÃO COM TERRA NO BRASIL, 2., São Luiz, 2008. Anais... São Luiz: PROTERRA, 2008.

FARIA, O. B.; STANZIONE, V. J. T. L.; MILLER, V. P. Avaliação do Teor de Argila em Características Físicas e Mecânicas de Adobe e Proposta de Ensaio para Determinação do Módulo de Elasticidade. In: SEMINÁRIO IBEROAMERICANO DE CONSTRUCCIÓN CON TIERRA, 7.; SEMINÁRIO ARGENTINO DE ARQUITECTURA Y CONSTRUCCIÓN CON TIERRA, 2., San Miguel de Tucumán, 2009. Anais... San Miguel de Tucumán: PROTERRA/UNT, 2009.
INSTITUTO DE PERMACULTURA DA MATA ATLÂNTICA. Solo Cimento. São Paulo: IPEMA, 2010.

JIMENEZ DELGADO, M. C.; GUERRERO, I. C. Earth Building in Spain. Construction and Building Materials, v. 20, p. 679-690, 2006.

JIMENEZ DELGADO, M. C.; GUERRERO, I. C. The Selection of Soils Unstabilised Earth Buildings: a normative review. Construction and Building Materials, v. 21, n. 2, p. 237-251, 2007.

MILANI, A. P. S. et al. Estudo Preliminar do Uso de Cimento e Aditivo DS $328^{\circledR}$ Como

Estabilizantes de Solo da Região do Pantanal, no Estado de Mato Grosso do Sul - Brasil. In: CONGRESSO DE ARQUITETURA E CONSTRUÇÃO COM TERRA NO BRASIL, 3., Campo Grande, 2010. Anais... Campo Grande: UFMS/PROTERRA, 2010.

MILOGO, Y.; HAJJAJI, M.; MOREL, J. C. Physical Properties, Microstructure and Mineralogy of Termite Mound Material Considered as Construction Materials. Applied Clay Science, v. 52, n. 1, p. 160-164, 2011.

MOREL, J. C.; PKLA, A.; WALKER, P. Compressive Strength Testing of Compressed Earth Blocks. Construction and Building Materials, v. 21, n. 2, p. 303-309, 2007.

MÚJICA, J. A. E.; LÓPEZ, P. D. E. Análisis del Desempeño Térmico de un Módulo Experimental de Vivienda de Block de Tierra Comprimido en Clima Cálido Subhúmedo. In: SEMINÁRIO IBEROAMERICANO DE CONSTRUCCIÓN CON TIERRA, 7.; SEMINÁRIO ARGENTINO DE ARQUITECTURA Y CONSTRUCCIÓN CON TIERRA, 2., San Miguel de Tucumán, 2009. Anais... San Miguel de Tucumán: PROTERRA/UNT, 2009.

NEVES, C. M. M. et al. Seleção de Solos e Métodos de Controle na Construção Com Terra: práticas de campo. San Lorenzo: PROTERRA, Universidad Nacional de Asunción, 2011.

NEVES, C.; FARIA, O. B. Programa InterLaboratorial PROTERRA: ensaios de adobes. In: SEMINÁRIO IBERO-AMERICANO DE CONSTRUÇÃO COM TERRA, 7.; CONGRESSO DE ARQUITETURA E CONSTRUÇÃO COM TERRA NO BRASIL, 2., São Luiz, 2008. Anais... São Luiz: PROTERRA, 2008. 
NEVES, C.; MILANI, A. P. S. BTC: blocos de terra comprimida. In: NEVES, C.; FARIA, O. B. (Orgs.). Técnicas de Construção Com Terra. Bauru: FEB-UNESP/PROTERRA, 2011.

SAHARA. Grupo Aguilar. Origem: arquitetura da terra. São Paulo: SAHARA, 2010.

SILVA, C. C. Comportamento de Solos Siltosos Quando Reforçados Com Fibras e Melhorados Com Aditivos Químicos e Orgânicos. Curitiba, 2007. 157 f. Dissertação (Mestrado em Engenharia Civil) - Escola de Engenharia, Universidade Federal do Paraná, Curitiba, 2007.

VENKATARAMA REDDY, B. V.; PRASANNA KUMAR, P. Cement Stabilised Rammed Earth: part A: compaction characteristics and physical properties of compacted cement stabilised soils. Materials and Structures, v. 44, n. 3, p. 681-693, 2011.
WALKER, P.; STACE, T. Properties of Some Cement Stabilised Compressed Earth Blocks and Mortars. Materials and Structures, v. 30, p. 545$551,1997$.

\section{Acknowledgements}

The authors thank Mr. Sydney (CEO of Dynasolo), for donating the chemical stabilizer, the technical staff of the laboratory of FEB-UNESP (Brazil), Gustavo Pinheiro and Israel Luiz Pereira dos Santos, and the undergraduate students of Civil Engineering, Cesar Burani Kowalski and Renan Viana Pepato, for their assistance with the tests.

\section{Obede Borges Faria}

Departamento de Engenharia Civil e Ambiental, Faculdade de Engenharia de Bauru | Universidade Estadual Paulista Júlio de Mesquita Filho | Av. Eng. Luiz E. C. Coube, 14-01, Vargem Limpa | Bauru - SP - Brasil | CEP 17033-360 | Tel.: (14) 3103-6112 Ramal 6112

E-mail: obede.faria@gmail.com

\section{Rosane Aparercida Gomes Battistelle}

Departamento de Engenharia Civil e Ambiental, Faculdade de Engenharia de Bauru | Universidade Estadual Paulista Júlio de Mesquita Filho | E-mail: rosane@feb.unesp.br

\section{Célia Neves}

Rede Ibero-americana PROTERRA; Rede TerraBrasil | $181823^{\text {rd }}$. Avenue Unit A | Seattle - WA - USA | ZIP 89122 | Tel: 1 (206) 4963063 | E-mail: cneves2012@gmail.com

\section{Revista Ambiente Construído}

Associação Nacional de Tecnologia do Ambiente Construído

Av. Osvaldo Aranha, $99-3^{\circ}$ andar, Centro

Porto Alegre - RS - Brasil CEP 90035-190

Telefone: +55 (51) 3308-4084

Fax: +55 (51) 3308-4054

www.seer.ufrgs.br/ambienteconstruido

E-mail: ambienteconstruido@ufrgs.br 